\title{
WILEY
}

\section{CHATHAM HOUSE}

The Jews. by Hilaire Belloc

Review by: Lucien Wolf

Journal of the British Institute of International Affairs, Vol. 1, No. 5 (Sep., 1922), pp. 159-

161

Published by: Wiley on behalf of the Royal Institute of International Affairs

Stable URL: http://www.jstor.org/stable/3014638

Accessed: 14/06/2014 13:41

Your use of the JSTOR archive indicates your acceptance of the Terms \& Conditions of Use, available at

http://www.jstor.org/page/info/about/policies/terms.jsp

JSTOR is a not-for-profit service that helps scholars, researchers, and students discover, use, and build upon a wide range of content in a trusted digital archive. We use information technology and tools to increase productivity and facilitate new forms of scholarship. For more information about JSTOR, please contact support@jstor.org. 


\section{REVIEWS.}

The Jews. By Hilatre Belloc. (Constable \& Co., London. 1922.)

THIs book is an ingenuous account of its author's desperate quest for a solution of what he takes to be the Jewish problem. His case is distinctly pathetic. He knows very little about the Jews, and his acquaintance with their history and literature resolves itself into little more than hasty generalisations from inadequate books of reference. At least this is the only conclusion that one can arrive at on the hypothesis of his sincerity. In these circumstances he has fallen an easy prey to the bogey-maniacs. The terms of the Jewish problem, as stated by him, are taken straight from the recent anti-Semitic essays of Mr. Gwynne and Mrs. Webster. He apparently knows nothing of their highly controversial character. He assumes, indeed, from the beginning, that they are proved, and actually admitted by everybody except a few dullards and liars. Small wonder then that his credulous and tender soul is troubled. He sees universal pogroms in the immediate future, and he strains himself in a veritable anguish to find the elements of a peaceful concordat.

Mr. Belloc's thesis is that European and American society is suffering from a prodigious indigestion. The unassimilable element is represented by the Jews, who are declared to be an alien and nomadic race, organised as a hostile nationality, who have insinuated themselves under the guise of a simple religious community into the bodies politic of the Christian nations. Their disguise has been accepted partly out of politeness and partly out of fear, but, none the less, digestion has proved impossible and the alien body is a source of permanent irritation. This irritation is aggravated by the airs of superiority which the Jews are said to give themselves, and by their increasing domination of politics and finance. Mr. Belloc does not state the symptoms of the indigestion in very convincing fashion. By a rare flash of insight he is inclined to think that the professed anti-Semites overdo their business, but he finds better evidence in what he alleges to be the universal Gentile habit of abusing the Jews behind their backs while saying pleasant things to their faces. This disloyalty $\mathrm{Mr}$. Belloc solemnly assures us is quite common among otherwise high-minded Gentiles, who are not only the ostensible friends of Jews but are even their partners in business or the husbands of Jewish wives (pp. 127-131). Not very complimentary to Mr. Belloc's own friends!

His remedy for this exasperating state of things, which he labours through eleven wearisome chapters to assure us is on the brink of a tragical dénouement, is characteristic of his simplicity. It seems to have been borrowed from Gilbert's Bab Ballad of "The Bishop and the Busman." The Bishop, it will be remembered, dealt with the unassimilable Jew Busman by insisting in public on his Jewish name and nose and beard, with the result that eventually the Jew shed all his racial characteristics and married the Bishop's daughter. Mr. Belloc pleads for a similar method, though he does not look for quite the same result. He asks that the convention of common citizenship 
between Jew and Christian shall be abandoned, that when a Christian meets a Jew he should insist on saluting him as such, on calling him Hash Baz Ben rather than Adolphus Brown, and of pointing out to him, in and out of season, that he is an alien and that he has no rightful place in the society of Occidental white men. Mr. Belloc is convinced that if this "frankness" of intercourse can be cultivated there will be no necessity for bloodshed or the revival of legal disabilities. Not that the Jew, as in the Ballad, will at once bend his nose outwards and grow auburn whiskers, but he will probably hasten to segregate himself of his own accord in a new form of Ghetto life. The final result would be that the long indigestion of Christendom would be cured and the Jew, it is to be supposed, would find his reward in the moral satisfaction of becoming once more his own outcast self.

Flippant people might be disposed to say unkind things of $\mathrm{Mr}$. Belloc; but this would be an ungracious return for the sincerity which emboldens him to risk ridicule in the cause of social peace. Besides, it would serve no useful purpose. What Mr. Belloc requires is a return of a little of his own "frankness." As a matter of fact, the Jewish problem, as he sees it, is an unhappy delusion. The physiological analogy on which he bases it misconceives the whole ethnographic history of Europe and still more of America. The Jews are not aliens. They are among the oldest of the Asiatic races which have peopled the better part of the Western world in an imperfect amalgam. Their roots have been struck deep in European ethnography, and their separateness, so far as it exists, is exclusively a matter of religious law, which does not differentiate them by more than eight per mille, or less than one per cent. from their Christian fellow-Europeans. The purity and unabsorbability of the Jewish race is a fantasy of the Romanticists which finds little support in anthropological science. That there is a Jewish type, or rather several Jewish types, is true, but they are the product of centuries of segregation in Europe, and even then are distinctly unstable. A pseudo-racial type which is the product of European conditions cannot reasonably be described as alien to Europe. The racial alienage of the Jews is, then, at best a very insecurely founded theory, and if the Jew is disliked the cause must be sought for elsewhere. Mr. Belloc's contention that there is also a Jewish political nationality, hostile to Christendom, is more serious, but unfortunately for him such a nationality does not exist. During the last thirty years two Jewish national movements have been started in Eastern Europe, but they are the creations of exclusively local conditions and very largely of local non-Jewish political theories, and they have found scarcely an echo among the established Jewish communities west of the Vistula. It is true that certain of the Zionists have even expounded the idea of a pan-Jewish nationality, but it has not found much support among the Zionists themselves, and it has been formally repudiated by the most representative organs of Jewish opinion in Western Europe and America. As for the alleged nomadic habits of the Jew, they are-so far as they existlike the similar habits of the Irish, purely the results of a chequered history. In normal and even in difficult circumstances no one is more deeply rooted to the land of his birth than the Jew.

All this is not to say that there is not a Jewish question, and that this question is not a source of some uneasiness. Within certainhappily narrow-limits there is such a question. In its larger manifestations it arises from prejudices inherited from twenty centuries 
of bitter religious controversies. In its narrower and more irritating form it is due to the social consequences of the long segregation of the Jews and the imposition on them of severe civil disabilities by the various States of Christendom, and more particularly of the persistence of this distorting and demoralising persecution down to our days in Eastern Europe. But this has nothing to do with racial rivalries and incompatibilities. It is a piece of essentially European politics, the price Europe has to pay for a terrible blunder of her own statecraft. It is strange to find Mr. Belloc proposing a repetition of this blunder as a solution of the very problem it has produced and which affrights him so deliriously.

LUCIEN WOLF.

\section{Foreign Governments at Work: an Introductory Study. By HERMaN Finer, B.Sc. (Econ.) Lond.}

The Treaty Settlement of Europe: Some Geographic and Ethnographic Aspects. By H. J. Fueure. (Humphrey Milford, Oxford University Press. 1921. 2s. 6d. net.)

THE Oxford University Press is bringing out a series of small volumes dealing with the most important of the current problems of the present day. The books seem to be intended as guides to those adult students who often in association, as by study circles and in other forms of society, aim at deeper insight and fuller knowledge than can be obtained by unorganised reading of newspapers, periodicals or popular works. Among the numerous volumes which have already been published, we have before us two which will be of special interest to members of the Institute. Of these the first, Foreign Governments at Work, by Herman Finer, gives an account of the governing institutions in France, Germany and the United States. It is a useful little book, all the more because of the very full bibliographical notes and references which will enable the student to pass on easily to more advanced study. This, and the other book also, are, however, of special interest because of the point of view from which they are written. We are introduced to the laboratories of new ideas, new ideas in which the guiding note is the attempt at a complete revision of all our current political thought and nomenclature so as to make it fit the changed conditions which are the result of modern industrial development. The result of this is to be seen in Mr. Finer's attitude towards the three governments with which he deals; while that towards France and the United States is very critical, for in both the author is intent on pointing out the vices and weaknesses of the system and its failure to produce good administration, he is full of appreciation of the new German constitution, which he characterises as-

" a loyal attempt, based upon careful study of foreign experience, to establish institutions which should give social and individual purpose, as known to-day, its fullest scope. The clauses on civic rights and duties, which space compels me to omit, are earnestly commended to the reader's attention. The Constitution is an example of conscious thought applied to a purpose, and that purpose a freer, fuller life."

The critical reader, though he may endorse the certificate of good intention, will, however, not omit to record that the constitution is an experiment, and we have no evidence at present to show that it will work. The clauses on civic rights and duties surely scarcely deserve 